Gregová R.

\title{
Structure of second-grade diminutives in Czech and Slovak. A corpus-based synchronic-diachronic analysis
}

\begin{abstract}
In Slavic languages, diminutivization is a highly productive morphological process. A diminutive marker can be attached to nouns, adjectives, verbs and adverbs. Secondary or even multiple diminutives are also possible. Considering the combinability of diminutive suffixes in nouns, Manova and Winternitz (2011) claim that only productive DIM1 suffixes function as DIM2 suffixes. The aim of this paper is to verify this idea on the basis of the analysis of data from Czech and Slovak. The DIM2 for the analysis were excerpted from the corpora. Neither Czech nor Slovak current sources apprehend diminutive markers as combinations of primary and secondary diminutive suffixes. The complex character of secondary diminutivizers is understood as a diachronic issue. Therefore, a historical analysis of all secondary diminutives was necessary. The research proved the assumption about the combinability of diminutive markers. The analysis also revealed that unproductive DIM2 suffixes are attached by substitution in both languages.

Key words: primary diminutive markers; secondary diminutive markers; Czech; Slovak; synchrony; diachrony.

Acknowledgements. I hereby thank Dušan Ptáček for his help with the analysis of the Czech data.

Citation. Gregová R. Structure of second grade diminutives in Czech and Slovak. A corpus-based synchronic-diachronic analysis. Vestnik Samarskogo universiteta. Istoriia, pedagogika, filologiia = Vestnik of Samara University. History, pedagogics, philology, 2021, vol. 27, no. 3, pp. 111-117. DOI: http://doi.org/10.18287/2542-0445-2021-27-3-111-117. (In English)

Information on the conflict of interests: author declares no conflict of interest.
\end{abstract}

(C) Gregová R., 2021

Renáta Gregová - Department of British and American Studies, Faculty of Arts, Pavol Jozef Šafárik University, 9, Moyzesova Street, Kosice, 040 01, Slovakia.

\section{НАУЧНАЯ СТАТЬЯ}

УДК 811

Дата поступления: 11.06.2021 рецензирования: 16.07.2021 принятия: 26.08.2021

\section{Структура диминутивов второго сорта в Чехии и Словакии. Синхронно-диахронический анализ на основе корпуса}

\author{
Рената Грегова \\ Университет Павла Йозефа Шафарика, г. Кошице, Словакия \\ E-mail: renata.gregova@upjs.sk. ORCID: http://orcid.org/0000-0003-4743-2559
}

\begin{abstract}
Аннотация: В славянских языках диминутивизация - это высокопроизводительный морфологический процесс. Уменьшительно-ласкательный маркер может быть прикреплен к существительным, прилагательным, глаголам и наречиям. Также возможны вторичные или даже множественные уменьшительные. Учитывая возможность комбинирования уменьшительных суффиксов в существительных, Manova и Winternitz (2011) утверждают, что только продуктивные суффиксы DIM1 функционируют как суффиксы DIM2. Цель данной статьи - проверить эту идею на основе анализа данных из Чехии и Словакии. DIM2 для анализа были взяты из корпусов. Ни чешские, ни словацкие современные источники не воспринимают уменьшительные указатели как комбинации первичных и вторичных уменьшительных суффиксов. Сложный характер вторичных диминутивизаторов понимается как диахроническая проблема. Следовательно, был необходим исторический анализ всех вторичных уменьшительных. Исследование подтвердило предположение о возможности комбинирования миниатюрных маркеров. Анализ также показал, что непродуктивные суффиксы DIM2 присоединяются путем подстановки в обоих языках.

Ключевые слова: первичные миниатюрные маркеры; вторичные миниатюрные маркеры; чешский язык; словацкий язык; синхронность; диахрония.

Благодарности. Автор благодарит Душана Птачека за его помощь в анализе чешских данных.

Цитирование. Gregová R. Structure of second grade diminutives in Czech and Slovak. A corpus-based synchronicdiachronic analysis // Вестник Самарского университета. История, педагогика, филология. 2021. Т. 27 , № 3. C. 111-117. DOI: http://doi.org/10.12287/2542-0445-2021-27-3-111-117.
\end{abstract}

Информация о конфликте интересов: автор заявляет об отсутствии конфликта интересов. 


\section{Introduction}

Diminutivization is a derivational process of transforming a word into its diminutive form, that is, the one with an attribute of diminutiveness which can be of a quantitative (small size) or a qualitative (affection) nature (cf., e.g., Zelinková 1993, Schneider 2003). For Slavic languages, diminutivization is highly productive and enables a diminutive affix to be attached to an already existing diminutive; for example, Czech strom 'tree' $\rightarrow$ DIM1 strom-ek 'small tree' $\rightarrow$ DIM2 strom-eč-ek 'very small tree'. Diminutives with one diminutive marker are called first-grade or primary diminutives (DIM1 - 'small x'). Diminutives with two diminutive suffixes (DIM2 - 'very small $x^{\prime}$ ) are referred to as secondary, second-grade or double diminutives in various sources (cf., e.g., Trnková 1991, Dunn, Khairov 2009).

Diminutives are created by adding a diminutive marker (or diminutive markers) to nouns, adjectives, verbs and adverbs. Slavic nominal diminutive markers are suffixes only (Panocová 2011). Taking into account the rich group of nominal diminutives, diminutive suffixes can be attached to all types of nouns: concrete nouns and abstract nouns, common nouns and proper nouns, as well as family members. With respect to their form, derivations from nouns denoting family members are similar to derivations from proper names and common nouns. Compare, for example, Czech/Slovak baba 'grandmother' $\rightarrow$ bab$k a$ 'grandmother-DIM1' $\rightarrow b a b-i c ̌-k a$ 'grandmotherDIM1-DIM2' with the Czech proper name Hana $\rightarrow$ Han-ka $\rightarrow$ Han-ič-ka and with the Czech/Slovak common noun ruka 'hand' $\rightarrow$ ruč-ka 'head-DIM1' $\rightarrow$ $r u c ̌-i c ̌-k a$ 'head-DIM1-DIM2'. However, with respect to semantics, the primary function of diminutive suffixes in family members and proper names is the expression of affection. But, considering Czech and Slovak diminutives from common nouns, they usually have both semantic values - qualitative and quantitative - and the real meaning of a diminutive can be fully disclosed only by context (Zelinková 1993, see also Gregová 2015) ${ }^{1}$.

1 This idea seems to be in contradiction with the prototypical understanding of diminutives as concepts expressing smallness (Schneider 2003, p. 10). However, the claim that the real meaning of both Slovak and Czech diminutives depends on context has its root not only in literature on diminutives (Štolc 1958, Zelinková 1993) but is also supported by research carried out on a sample of 55 Slovak respondents (university students) who were given a questionnaire with a list of 60 diminutives divided into three categories (both first-grade and second-grade diminutives were included) - (1) common inanimate nouns, (2) common animate nouns and (3) proper names and family members. They wereaskedtoconnectthemeaningofthegiven DIMnounwith(a)somethingsmall, (b)something dear or (c) something both small and dear at the same time. It was only in the category of proper names and family members where the meaning of affection prevailed (66\%). Otherwise, the respondents perceived the given diminutive forms as forms expressing both smallness and affection (cf. Schneider 2003 for similar results in different languages).
As already mentioned, in Slavic languages, diminutivization is a very productive morphological process. A Slavic language has about ten DIM1 suffixes on average. Since all DIM1 suffixes derive the same meaning, one expects them to combine freely with each other in secondary diminutives, but of all DIM1 suffixes only a few can be used as DIM2 suffixes (see below). Manova and Winternitz (2011) report heavy restrictions on the combinability of diminutive suffixes in double and multiple diminutives in Bulgarian and Polish. The authors claim that only productive DIM1 suffixes surface as DIM2 suffixes and that all combinations of DIM1DIM2 suffixes are fixed, in the sense that there are also phonological and morphological constraints on the combinability of the suffixes. This study checks their observations against data from Czech and Slovak but goes beyond Manova and Winternitz in validating DIM1-DIM2 combinations in corpora. A major problem with the analysis of secondary diminutives is the verification of the examples, and one tends to believe that secondary diminutives are hardly used in written texts. Consequently, the Czech second-grade diminutives analyzed in this paper were extracted from the Czech National Corpus, version SYN2015 (Křen et al. 2015) and the analyzed Slovak second-grade diminutives were excerpted from the Slovak National Corpus, version Prim-7.0-public-all (http://korpus. sk/structure1_en.html). Both corpora were released in 2015 and are lemmatized and morphologically tagged $^{2}$.

It has to be noted here that none of the current $\mathrm{Czech}$ or Slovak sources analyzes the structure of the secondgrade diminutive suffixes in terms of DIM1-DIM2 suffix combinations. In both languages, diminutive markers fall into two categories: primary diminutive markers and secondary diminutive markers (cf., e.g., Horecký 1959, 1971, Štícha 1978, Furdík 2004, Gregová 2015) without further analysis of secondary diminutivizers (see section 3). Moreover, in both analyzed languages, the process of diminutivization was historically accompanied by various palatalization changes. Hence, a diachronic phonological analysis of the data is necessary to uncover the true form of DIM1 and DIM2 suffixes.

\section{Methods}

The method of analysis encompasses several steps:

1) All DIM1 and DIM2 suffixes in Czech and Slovak were gathered from the relevant literature to prepare a survey of diminutive markers used for the creation of primary and secondary diminutives in the contemporary languages.

2) A search was conducted in the Czech and Slovak National Corpora for words terminating in DIM2 suffixes.

${ }^{2}$ The preliminary results of this research (gained in co-operation with Stela Manova from the University of Vienna) were presented at the annual meeting of the Slavic Linguistics Society (Ljubljana, 2017). Later, the research was extended with a more detailed diachronic analysis (see below). 
3) The lists of all extracted forms were manually checked to ensure that the nouns found are secondgrade diminutives since there are words in both languages that have the form of DIM2 but the meaning of DIM1, as I will explain below. Those forms were excluded from further analysis.

The data gained from the analysis were distributed into two big groups:

1. Nouns that express smallness and affection, i.e. common nouns

2. Nouns that express affection only

2.1. Proper names note 2 ).

2.2. Family members (see also Introduction and

This grouping was done for two reasons. First, because the research on second-grade diminutives in the literature is based on common nouns, and, second, to see which group of nouns are the most numerous in a corpus of written texts. The analysis of all Czech and Slovak secondary diminutives can be found in section Findings. The results are summarized and commented on in section Conclusion.

\section{Literature review}

\section{First-grade diminutives (DIM1) in Czech}

In the Czech language, there are the DIM1 suffixes -ek, -ík for masculine nouns, -ka for creating firstgrade diminutives from feminine nouns, and -ko and -átko for neuter nouns (Štícha 1978, p. 114), as illustrated in the following examples:

$\begin{array}{lllll}\text { masculine: } & \begin{array}{l}\text { strom 'tree' } \rightarrow \\ \text { 'tree-DIM' } \\ \text { les 'forest' } \\ \text { 'forest-DIM' }\end{array} & \rightarrow \text { DIM1 } & & \\ \text { feminine: } & \begin{array}{l}\text { noha 'foot' } \rightarrow \\ \text { 'foot-DIM' }\end{array} & \text { DIM1 nož-ka } \\ \text { neuter: } & \begin{array}{l}\text { bricho 'belly' } \\ \text { bříšso 'belly-DIM' } \\ \text { košte 'broom' }\end{array} & \rightarrow & \text { DIM1 } \\ & \text { košt'-átko 'broom-DIM' } & \text { DIM1 }\end{array}$

\section{First-grade diminutives (DIM1) in Slovak}

In present-day standard Slovak, the DIM1 suffixes for masculine nouns are -ok, -ík/-ik, -ček/-tek and -ko. The DIM1 suffix -ka combines with feminine nouns, neuter first-grade diminutives are formed by the suffix -ko, and the suffix -atko/-iatko/-ätko is used to create diminutive forms from nouns denoting young animals (see, e.g., Štolc 1958, Horecký 1971), for example:

$$
\text { masculine: } \begin{gathered}
\text { stĺp 'pole' } \\
\text { 'pole-DIM' }
\end{gathered} \rightarrow \text { DIM1 stĺp-ok³ }
$$

\footnotetext{
${ }^{3}$ In this section, all examples are given in the form of a word-formative structure that is binary (word-formative base + suffix), contrary to section Findings, where the morphemic structure of words is used.
}

\author{
most 'bridge' $\rightarrow$ DIM1 most-ík \\ 'bridge-DIM' \\ strom 'tree' $\rightarrow$ DIM1 strom-ček \\ 'tree-DIM' \\ Marcel $\rightarrow$ DIM1 Marcel-ko
}
feminine: hlava 'head' $\rightarrow$ DIM1 hláv-ka 'head-DIM'
neuter: $\quad$ čelo 'forehead' $\rightarrow$ DIM1 čiel-ko 'forehead-DIM'
kozl'a 'yeanling' $\rightarrow$ DIM1 kozl-iatko 'yeanling-DIM'

\section{Second-grade diminutives}

In current Central European linguistics, diminutives are studied within the field of lexicology or word-formation. As mentioned above, none of the synchronic Czech or Slovak sources analyzes secondgrade diminutive markers as a combination of DIM1 and DIM2 suffixes. The fact that, for example, the Slovak DIM2 suffix -íček is given by the combination of the DIM1 suffix -ík and the DIM2 suffix -ek (see below) is understood as a diachronic issue (see, e.g., Stolc 1957). The only information that somehow indicates the complex character of second-grade diminutive suffixes is that, from a genetic point of view, second-grade diminutives are derived from firstgrade diminutives, thus creating sets with a gradually increasing diminutive meaning (cf., e.g., Štolc 1957, Němec 1968), for example, ryba 'fish' $\rightarrow$ ryb-ka 'fish-DIM' $\rightarrow$ ryb-ička 'fish-DIM-DIM' ${ }^{4}$ Following on from this, the DIM2 suffixes will be given in the form in which they occur in the sources cited (see also note 4$)$.

\section{Second-grade diminutives (DIM2) in Czech}

Štícha (1978, p. 114), in his analysis of Czech second-grade diminutives, reports the following DIM2 suffixes: -eček, -íček, -ánek, -ínek, -oušek and -áček for masculine nouns, for instance:

\section{DIM'}

dom 'house' $\rightarrow$ DIM2 dom-eček 'house-DIM-

les 'forest' $\rightarrow$ DIM2 les-íček 'forest DIM-DIM'

nos 'nose' $\rightarrow$ DIM2 nos-ánek 'nose DIM-DIM'

táta 'dad' $\rightarrow$ DIM2 tat-ínek 'dad-DIM-DIM'

děda 'grandpa' $\rightarrow$ DIM2 ded-oušek 'grandpaDIM-DIM'

$$
\text { syn 'son' } \rightarrow \text { DIM2 syn-áček 'son-DIM-DIM' }
$$

${ }^{4}$ The Morpheme Dictionary of Slovak (Sokolová et al. 1999), which offers the morpheme structure of all Slovak words, divides second-grade diminutive suffixes into socalled sub-morphs without meaning and core morphemes which together create one extended hyper-morpheme, for example dám-ič: $k$-a'lady-DIM', where-ič: is a submorph without meaning connected to the coremorphemek-(Sokolová et al., p. 12). This type of representation of second-grade diminutive markers indicates their complex character. 
The DIM2 feminine suffixes are -ička, -ečka and, less frequently, -enka, -inka, -unka and -uška (ibid.):

bota 'shoe' $\rightarrow$ DIM2 bot-ička 'shoe DIM-DIM' čára 'line' $\rightarrow$ DIM2 čár-ečka 'line-DIM-DIM' děva 'maid' $\rightarrow$ DIM2 děv-enka 'girl-DIM-DIM' teta 'aunt' $\rightarrow$ DIM2 tet-inka 'aunt-DIM-DIM' dcera 'daughter' $\rightarrow$ DIM2 dcer-unka 'daughterDIM-DIM'

dcera 'daughter' $\rightarrow$ DIM2 dcer-uška 'daughterDIM-DIM'

The second-grade diminutives from neuter nouns are created by the suffixes -ečko/-éčko, -íčko/-ičko and -inko (ibid.):

víno 'wine' $\rightarrow$ DIM2 vín-ečko 'wine-DIM-DIM' DIM'

zrno/zrní 'grain' $\rightarrow$ DIM2 zrn-íčko 'grain-DIM-

oko 'eye' $\rightarrow$ DIM2 oč-inko 'eye-DIM-DIM'

\section{Second-grade diminutives (DIM2) in Slovak}

The masculine DIM2 suffixes are -íček/-iček, -oček and, less frequently, -enko/-inko and -uško (cf. Štolc 1958; Zelinková 1993), for instance:

pes 'dog' $\rightarrow$ DIM2 ps-íček 'dog-DIM-DIM'

list 'leaf' $\rightarrow$ DIM2 líst-oček 'leaf-DIM-DIM'

otec 'father' $\rightarrow$ DIM2 oc-inko 'father-DIM-DIM' DIM'

dedo 'grandpa' $\rightarrow$ DIM2 ded-uško 'grandpa-DIM-

The most frequent feminine DIM2 suffixes in Slovak are -ička and -očka/-ôčka (Horecký 1971, p. 167). On rare occasions, the DIM2 suffixes -enka/ienka/-inka and -uška are used. For example:

hlava 'head' $\rightarrow$ DIM2 hlav-ička 'head-DIM-DIM' DIM'

píšt'ala 'pipe' $\rightarrow$ DIM2 píšt’al-ôčka 'pipe-DIM-

duša 'soul' $\rightarrow$ DIM2 duš-inka 'soul-DIM-DIM'

mama 'mum' $\rightarrow$ DIM2 mam-uška 'mum-DIMDIM'

The neuter DIM2 suffixes are -ičko/-íčko, -ečko/iečko, -očko/-ôčko and -úško (Zelinková 1993, p. 39), as illustrated by the following examples:

oko 'eye' $\rightarrow$ DIM2 oč-ičko 'eye-DIM-DIM'

víno 'wine' $\rightarrow$ DIM2 vín-ečko 'wine-DIM-DIM'

kladivo 'hammer' $\rightarrow$ DIM2 kladiv-ôčko 'hammer-

DIM-DIM'

vrece 'sack' $\rightarrow$ DIM2 vrec-úško 'sack-DIM-DIM'

\section{Findings}

If one wants to see the real form of DIM2 suffixes in Czech and Slovak on the basis of the structure of DIM1 and DIM2 suffixes, that is, to follow Manova and Winternitz's (2011) understanding of DIM2 suffixes as combinations of DIM1 and DIM2 suffixes (which means that DIM2 = DIM1 + DIM1, but also DIM2 = DIM1 + DIM2), and thus to (dis)prove the idea of the combinability of diminutive suffixes, a diachronic analysis is necessary. As Štolc mentions, from the synchronic point of view, some linguistic phenomena show themselves as a complex, and their structure can be clarified only historically (1958, p. 43). This is the case with diminutivization.

For example, in both Czech and Slovak, there is a primary masculine diminutive suffix $-i k$ and a secondary masculine diminutive suffix -ícek. The DIM2 suffix -iček developed from the DIM1 marker $-i k$ and the DIM2 suffix -ek. The suffix -ek evolved via a historical change: the primary diminutive ending in the diminutive element -k- was followed by the diminutive marker $-b k b$ again:

$$
\text { *-ik-bkъ }>\text {-ič-bkъ }>\text {-íček }
$$

The vowel -e in the final output of this process is an appropriate equivalent for the soft sign (yer) b (Śtolc 1958, p. 61). The change of the DIM1 element -k- into -č- in DIM2 is the result of the Proto-Slavonic palatalization of velars (for details, see e.g. Krajčovič 1988; Manova 2011).

The structure of the secondary feminine diminutive marker -ick $a$ can be explained in the same way: the suffix -ička encompasses the DIM1 marker $*_{-i k}>$ $-i \check{c}$ - which modifies the word-formative base and the DIM2 suffix * $*_{-b k}>-k a$ :

$$
\text { *vod-ik-ьka > vod-ič-ka (Štolc 1958, p. 66) }
$$

The historical scheme *-bk-bk(o/a/e) $>$-ьč-bk(o/ $\mathrm{a} / \mathrm{e})^{5}+$ replacement of -b- with an appropriate vowel will be applied to the analysis of all Czech and Slovak secondary diminutives.

\section{Analysis}

From the viewpoint of morphological typology, the Slavic languages belong to the inflecting-fusional type, that is, in all of them, there is a clear difference between derivational and inflectional suffix slots (see Manova, Aronoff 2010 for further details).

The structure of the Slavic word can be represented as follows (see figure).

\footnotetext{
${ }^{5}$-o is a grammatical ending for masculine nouns,-a for
} feminine nouns and the element-e indicates neuter gender.

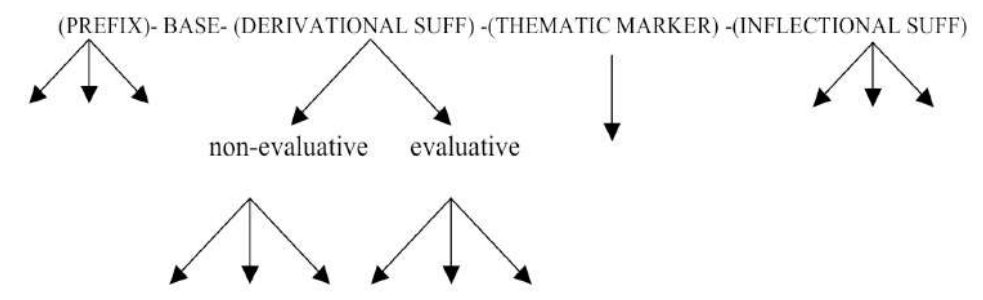


Only the slot BASE is always filled in; the other slots do not have to be. Thematic markers can be omitted since they only occur in the structure of verbs. Nominal diminutives are derived exclusively by suffixes and that is why the prefix slot can be excluded, too. Consequently, the structure important for the analysis is:
BASE

\section{DER}

\section{DIM1 - DIM2 - INFLECTIONAL SUFFIX}

For example, ruka 'hand' $\rightarrow$ ručka 'hand-DIM1' $\rightarrow$ ručička 'hand-DIM2' is analyzed as:

ruč-k-a $\rightarrow$ base-DIM1-inflectional suffix ruč-ič-k-a $\rightarrow$ base-DIM1-DIM2-inflectional suffix

\section{Czech second-grade diminutives from the corpora}

87 word forms were extracted from the Czech national corpus. However, as already indicated in section 2, the detailed evaluation of the individual items has shown that 15 of those diminutives have the form of DIM2 (12 common nouns and three family members), but they function as DIM1, for example,

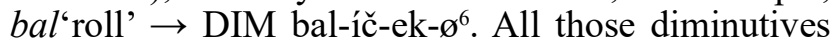
were excluded from further analysis. The whole issue will be discussed below. The remaining 72 second-grade diminutives (by form and meaning) fall into three categories: $86.11 \%$ are common nouns, $8.33 \%$ are proper names, and family members represent $5.56 \%$ of the data.

In all three categories (see Table 1 for details), the DIM2 suffix -ek combines with DIM1 nouns ending in -ek or -ík, and the suffix -k- ${ }^{7}$ is used with first-grade diminutives ending in -k-a and -k-o, for example:

$$
\begin{aligned}
& \text { DIM2 -ek- } \\
& \text {-ek+-ek-ø: rám 'frame' } \rightarrow \text { rám-ek-ø } \rightarrow \\
& -i k+-e k-\varnothing: \quad \text { kün̆ 'horse' } \rightarrow \text { kon-ik-ø } \rightarrow \\
& \text { kon-ič-ek-ø }
\end{aligned}
$$

DIM2 - $k$ - (epenthetic vowel i/e)

$-k+-k-a: \quad$ hlava 'head' $\rightarrow$ hláv- $k-a \rightarrow$ hlav-ič-k-a

kniha 'book' $\rightarrow$ kniž- $k-a \rightarrow k n i z ̌-e c ̌-k-a$ část 'part' $\rightarrow$ část-k-a $\rightarrow$ ćást-eč- $k-a$

(epenthetic vowel i/i/e)

$-k+-k-o: \quad$ slovo 'word' $\rightarrow$ slüv-k-o $\rightarrow$ slov-ič- $k-o$ $o k o$ 'eye' $\rightarrow$ oč- $k-o \rightarrow o c ̌-i c ̌-k-o$

misto 'place' $\rightarrow$ mist- $k-O^{8} \rightarrow$ mist-eč- $k-o$

6 The symbol -ø- (also known as the so-called morphemic zero or empty morpheme, see e.g. Sabol 1989) is used when there is no inflectional suffix, as, for example, in the nominative singular of masculine nouns.

${ }^{7}$ Although the segment -k- seems to be an infix, it is a (diminutive) suffix(see structure of the Slavic word above).

${ }^{8}$ This is only morphologically possible DIM1 form of the word misto 'place'.
The Czech data reveal one peculiarity: in the group of family members, there is a noun with the meaning

\begin{tabular}{|c|c|c|}
\hline $\begin{array}{c}\text { Noun } \\
\text { ending in* }\end{array}$ & $\begin{array}{c}\text { DIM1 } \\
\text { suffixes }\end{array}$ & DIM2 suffixes \\
\hline \multirow[t]{3}{*}{$-C^{* *}$} & -ek- & -ek- \\
\hline & -ík- & -ek- \\
\hline & $-\mathrm{k}-$ & $-\mathrm{k}-$ \\
\hline \multirow[t]{3}{*}{$\mathbf{- a}$} & $-\mathrm{k}-$ & $-\mathrm{k}-$ \\
\hline & & -unk-(unproductive ${ }^{* * *}$ ) \\
\hline & -ík- & -ek- \\
\hline$-\mathrm{e}$ & $-\mathrm{k}-$ & $-\mathrm{k}-$ \\
\hline \multirow[t]{2}{*}{-0} & -ík- & -ek- \\
\hline & $-\mathrm{k}-$ & $-\mathrm{k}-$ \\
\hline
\end{tabular}
of DIM2 whose form is derived in a different way:

dcera 'daughter' $\rightarrow$ dcer- $k-a \rightarrow$ dcer-unk- $a$

\section{Table 1. Combinability of DIM suffixes in Czech}

* The endings of nouns presented here are endings in nominative singular.

** C stands for consonant.

*** Unproductive suffixes are attached by substitution, i.e., they do not combine with DIM1 suffixes but substitute them.

\section{Slovak second-grade diminutives from the corpora}

The total number of word forms selected from the Slovak national corpus was 83 . But, similarly to the Czech data, 13 of the selected diminutive nouns (11 common nouns, one proper name and one family member) were excluded from further evaluation. They have the form of DIM2, but function as DIM1, for example, chyba'mistake' $\rightarrow$ DIM chyb-ič- $k$ - $a$ (for details, see section 5.2). The remaining 70 secondgrade diminutives represent the basic types of nouns as follows: $58.57 \%$ common nouns, $28.57 \%$ proper names and $12.86 \%$ family members.

A productive DIM2 suffix in Slovak (see also Table 2) is -ek- for first-grade diminutives ending in -ik/-ík or -ok, for example:

$-i k+$-ek-ø: $\quad$ mráz 'frost' $\rightarrow$ mráz-ik- $\emptyset \rightarrow$ mráz-ič-ek-ø $-i k+-e k-\varnothing: \quad k o ̂ n$ 'horse' $\rightarrow$ kon-ík-ø $\rightarrow$ kon-íč-ek-ø -ok+ -ek-ø: list 'leaf' $\rightarrow$ líst-ok-ø $\rightarrow$ líst-oč-ek-ø

The DIM2 suffix -k- is used with DIM1 nouns ending in $-\mathrm{k}-\mathrm{a}$ and $-\mathrm{k}-\mathrm{o}$ :

$-k$ - (epenthetic vowels $\mathrm{i} / \mathrm{o} / \mathrm{o})$

$-k-+-k-a: \quad h l a v a$ 'head' $\rightarrow$ hláv-k-a $\rightarrow$ hlav-ič $-k-a$ kniha 'book' $\rightarrow$ kniž-k-a $\rightarrow$ kniž-ôč-k-a

čast' 'part' $\rightarrow$ čiast-k- $a \rightarrow$ čiast-oč- $k-a$

(epenthetic vowels i/ie/e/ô/o)

$-k-+-k-o: \quad$ slovo 'word' $\rightarrow$ slov- $k-o \rightarrow$ slov-ič- $k o$ zrno 'corn' $\rightarrow$ zrn-k-o $\rightarrow$ zrn-ieč-ko kladivo 'hammer' $\rightarrow$ kladiv-k-o $\rightarrow$ kladiv-ôč-ko

The Slovak data revealed idiosyncrasies, too. DIM2 nouns for family members are derived in a different way: 
teta 'aunt' $\rightarrow$ tet- $k-a \rightarrow$ tet-ušk-a

dcéra 'daughter' $\rightarrow$ dcér- $k-a \rightarrow$ dcér-enk-a mama 'mother' $\rightarrow$ mam- $k-a \rightarrow$ mamul-ienk-a dedo 'grandfather' $\rightarrow$ ded-k-o $\rightarrow$ ded-ušk-o

However, consider the following examples: tato 'father' $\rightarrow$ tat $-k-o \rightarrow$ tat-íc-k-o (cf. slovo 'word' $\rightarrow$ slov- $k-o \rightarrow$ slov-íc $-k-o$ )

mama 'mother' $\rightarrow$ mam- $k-a \rightarrow$ mam-ič- $k-a$ (cf. hlava 'head' $\rightarrow$ hláv-k-a hlav-ič-k-a)

Table 2. Combinability of DIM suffixes in Slovak

\begin{tabular}{|c|c|c|}
\hline $\begin{array}{c}\text { Nouns } \\
\text { ending in* }\end{array}$ & $\begin{array}{c}\text { DIM1 } \\
\text { suffixes }\end{array}$ & DIM2 suffixes \\
\hline \multirow[t]{3}{*}{$-\mathbf{C}^{* * *}$} & $-1 \mathrm{k} /-\mathrm{ik}-$ & -ek- \\
\hline & -ok- & -ek- \\
\hline & $-\mathrm{k}-$ & $-\mathrm{k}-$ \\
\hline \multirow[t]{3}{*}{$-\mathbf{a}$} & $-\mathrm{k}-$ & $-\mathrm{k}-$ \\
\hline & & -ušk- (unproductive) \\
\hline & & -enk-/-ienk- (unproductive) ) $^{* * *}$ \\
\hline \multirow[t]{3}{*}{-0} & $-\mathrm{k}-$ & $-\mathrm{k}-$ \\
\hline & $-\mathrm{k}-$ & -ek- \\
\hline & & (unproductive) \\
\hline
\end{tabular}

* See note 10 .

** See note 11 .

$* * *$ See note 12 .

Comparison of second-grade diminutives in Czech and Slovak

Looking at both languages under analysis, we can find similarities but also differences in the way the second-grade diminutives are formed. As to the similarities, both Czech and Slovak use two suffixes for the derivation of DIM2 nouns: $-e k$ - and $-k$-. Both are productive. There are two differences between the Czech and the Slovak DIM2 suffixes:

(1) Slovak uses -ek for the derivation of DIM1 much less frequently than Czech does, for example:

Cz. rám 'frame' $\rightarrow$ rám-ek-ø $\rightarrow$ rám-eč-ek-ø

S1. rám 'frame' $\rightarrow$ rám-ik-ø $\rightarrow$ rám-č-ek-ø

(2) The attachment of phonologically identical DIM2 suffixes does not imply the same epenthetic vowel in these two languages, as illustrated by the following examples:

Cz. DIM2- $k-a$ (epenthetic vowel $i / e$ ) vs. S1. DIM2 $-k$ - $a$ (epenthetic vowels $i / \hat{o} / o$ )

Cz. DIM2-k-o (epenthetic vowel i/i/e) vs. S1. DIM2 -k-o (epenthetic vowels i/ie/e/ô/o).

And, finally, in both languages there are words with the form of second-grade diminutives that function as first-grade diminutives.

\section{Diminutives with the form of DIM2 but the function of DIM1}

As specified above, in Czech and Slovak, there are word forms with the structure of second-grade diminutives that have the meaning of first-grade diminutives. In Czech, these are dédeček (děd-eček-ø), holčička (holč-ič-k-a), písnička (písn-ič-k-a), balićek (bal-íč-ek-ø), lavička (lav-ič-k-a), městečko (měst-eč-k-o), krabička (krab-ič-k-a), žebríček (žebřríč-ek-ø), kolečko (kol-eč-k-o), sluničko(slun-íč-k-o), sestřička (setř-ič-k-a), tyčinka (tyč-ink-a), chlapeček (chlap-eč-ek-ø), cestička (cest-ič-k-a) and lahvička (lahv-ič-k-a).

In Slovak, these are sestrička (sestr-ič-k-a), ružička (ruž-ič-k-a), pesnička (pesn-ič-k-a), vodička (vod-ič-k-a), Petruška (Petr-uš-k-a), dušička (duš-ičk-a), chybička (chyb-ič-k-a), flaštička (fl'ašt-ič-k-a), slzička (slz-ič-k-a), kostička (kost-ič-k-a) andslniečko (sln-ieč-k-o).

This phenomenon is quite frequent and occurs for the following reasons:

(1) polysemy of morphemes: for example, formally, the structure of the words baliček and psiček is identical:

$$
\begin{aligned}
& \text { bal'roll' } \rightarrow \text { bal-ík- } \varnothing \rightarrow \text { bal-íč-ek- } \varnothing
\end{aligned}
$$

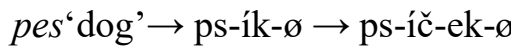

However, -ík- in psík is a diminutive suffix, whereas -ík-in balik is a derivative morpheme without a diminutive meaning (bal 'roll' vs. balík 'parcel'), and that is why psicek is a second-grade diminutive by form and meaning and baliček is DIM2 formally with the meaning of DIM1,

(2) a first-grade diminutive suffix has lost its diminutive meaning, for example the Czech diminutive suffix -ic-e: láv-k-a 'bridge' $\rightarrow l a v-i c-e$ 'school desk' $\rightarrow l a v-i c ̌-k-a$ DIM1 from both lávka and lavice or krabice 'box' $\rightarrow k r a b-i c ̌-k$ - $a$ 'box-DIM' (for details, see Štícha 1978)

(3) a first-grade diminutive as a whole has lost its diminutive meaning and become lexicalized, for example, voda'water' $\rightarrow$ vod- $k-a$ 'vodka' $\rightarrow$ vod-ič$k$ - $a$ 'voda-DIM' (Štolc 1958),

(4) a diminutive form of a word does not have a diminutive meaning, but functions as a normal colloquial variant of a basic noun, for example, piseň 'song' - písnička 'song' (Štícha 1978).

\section{Conclusion}

The paper aimed to analyze the structure of secondary diminutive nouns in Czech and Slovak so as to verify the claim that only productive DIM1 suffixes can be used as DIM2 suffixes (Manova, Winternitz 2011). The analysis was based on data from corpora and the secondary diminutives gained from them were divided into three categories - common nouns, proper names and family members - to find out which category of DIM2 nouns is the most numerous in the corpora of written texts. Although the results are similar for both languages - common nouns are the most frequent and family members are the least numerous - there is a difference between them: in the Slovak language, the discrepancy between the frequency of the occurrence of common nouns with 
regard to proper names and family members is not as big as in the Czech language.

The understanding of DIM2 suffixes as a combination of DIM1 and DIM2 suffixes in both analyzed languages is a diachronic issue, and that is why a historical analysis of all DIM2 suffixes was necessary. The research has shown that in both languages, productive DIM1 suffixes are used as DIM2 suffixes too, that is, productive DIM2 = DIM1+DIM1 and unproductive DIM2 suffixes are attached by substitution. This finding supports the results of the analysis of data from Bulgarian and Polish (cf. ibid.). The secondary aim of the research was to compare the structure of DIM2 from common nouns with the structure of DIM2 from proper names and family members, which are usually neglected in the literature on diminutives. The results of the analysis are similar for both languages: the structures of secondary diminutives of common nouns and of proper names are identical. Peculiarities (the substitution of a productive DIM1 suffix by an unproductive DIM2 suffix) can be found in the category of family members.

\section{References/Библиографический список}

Dunn, Khairov 2009 - Dunn J., Khairov S. (2009) Modern Russian Grammar. Abingdon: Routledge. Available at: https:// chamilanguerussepourtous.nethouse.ru/static/doc/0000/0000/0238/238082.st7fzxcuqu.pdf.

Furdík 2004 - Furdik J. (2004) Slovenská slovotvorba. Prešov: Náuka. (In Slovak)

Gregová 2015 - Gregová R. (2015) Slovak. In: Edinburgh Handbook of Evaluative Morphology, pp. $296-305$. Edinburgh: Edinburgh University Press. Available at: https://www.jstor.org/stable/10.3366/j.ctt1g09zkx.

Horecký 1959 - Horecký J. (1959) Slovotvorná sústava slovenčiny. Bratislava: Vydavatel'stvo Slovenskej akadémie vied. (In Slovak)

Horecký 1971 - Horecký J. (1971) Slovenská lexikológia. I: Tvorenie Slov. Bratislava: Slovenské pedagogické nakladatel'stvo. (In Slovak)

Slovak National Corpus - Available at: http://korpus.sk/structure1_en.html - Slovak Academy of Sciences, n.d. Slovak National Corpus.

Krajčovič 1988 - Krajčovič R. (1988) Vývin slovenského jazyka a dialektológia. Bratislava: Slovenské pedagogické nakladatel'stvo. Available at: https://pdf.truni.sk/e-ucebnice/vsjd. (In Slovak)

Křen et al. 2015 - Křen M., Cvrček V., Čapka T., Čermáková A., Hnátková M., Chlumská L., Jelínek T., Kováŕíková D., Petkevič V., Procházka P., Skoumalová H., Škrabal M., Truneček P., Vondřička P., Zasina A. (2015) SYN2015: reprezentativni korpus psané češtiny. Ústav Českého národního korpusu FF UK, Praha. Available at: http:// www.korpus.cz. (In Chech)

Manova, Aronoff 2010 - Manova S., Aronoff M. (2010) Modeling affix order. Morphology, no. 20 (1), pp. 109-131. DOI: http://dx.doi.org/10.1007/s11525-010-9153-6.

Manova 2011 - Manova S. (2011) Understanding Morphological Rules: With Special Emphasis on Conversion and Subtraction in Bulgarian, Russian and Serbo-Croatian. Dordrecht: Springer. Available at: https://www.semanticscholar. org/paper/Understanding-Morphological-Rules\%3A-With-Special-on-Manova/3373f3d2efd0319f07bea9eb2734206985 9434ed.

Manova, Winternitz 2011 - Manova S., Winternitz K. (2011) Suffix order in double and multiple diminutives: with data from Polish and Bulgarian. Studies in Polish Linguistics, no. 6, pp. 115-138. Available at: https://ruj.uj.edu.pl/ $\mathrm{xmlui} / \mathrm{bitstream} /$ handle/item/68315/manova winternitz suffix order in double and multiple diminutives 2011. pdf? sequence $=1 \&$ isAllowed $=\mathrm{y}$.

Němec 1968 - Němec I. (1968) Vývojové postupy české slovní zásoby. Praha: Nakladatelství Československé akademie věd. Available at: https://vokabular.ujc.cas.cz/moduly/literatura/texty/NemecPostupy1968. (In Czech)

Panocová 2011 - Panocová R. (2011) Evaluative suffixes in Slavic. Bulletin of the Transilvanian University of Brasov, Series IV: Philology and Cultural Studies, vol. 53, no.1, pp. 175-182. Available at: http://anyflip.com/rgcu/pbnc.

Sabol 1989 - Sabol J. (1989) Syntetická fonologická teória. Bratislava: Jazykovedný ústav L’udovíta Štúra Slovenskej akadémie vied. (In Slovak)

Schneider 2003 - Schneider K. (2003) Diminutives in English. Tübingen: Niemeyer. DOI: https://doi. org/10.1515/9783110929553.

Sokolová et al. 1999 - Sokolová M., Moško G, Šimon F., Benko V. (1999) Morfematický slovník slovenčiny. Prešov: Náuka. Available at: https://scholar.google.ca/citations?view_op=view_citation\&hl=en\&user=DxooD2UAAAAJ\&citation_for view=DxooD2UAAAAJ:u5HHmVD_uO8C. (In Slovak)

Štícha 1978 - Štícha F. (1978) Substantiva deminutivní formy s lexikalizovaným významem. Naše řeč, vol. 61, no. 3, pp. 113-127. Available at: http://nase-rec.ujc.cas.cz/archiv.php?art=6051. (In Czech)

Štolc 1958 - Štolc J. (1958) K morfológii deminutív v slovenčine. Jazykovedné štúdie III, pp. 19-81. (In Slovak)

Trnková 1991 - Trnková J. (1991) O substantívnej deminutívnej derivácii v slovenčine. Slovenská reč, vol. 56, no. 2, pp. 87-95. (In Slovak)

Zelinková 1993 - Zelinková K. (1993) Sústava slovenských deminutív. In: Zborníkk 11. medzinárodnému zjazdu slavistov, pp. 28-44. Nitra: Vysoká škola pedagogická. (In Slovak) 